\title{
The Textual Ethics of Dada: A Case Study
}

I nearly did break — shattered to unrecognizableness — to mineownself $[\ldots]$ the excruciating horror - awful wonder [...] nobody but victim can know - and never be able to depict it [...] But — I rallied — since still I am in life.

Elsa von Freytag-Loringhoven to Sarah Freedman, $1927^{1}$

Dada was born of a moral need, an implacable will to achieve a moral absolute, of a profound sentiment that man, at the center of all creations of the spirit, must affirm his primacy over notions emptied of all human substance, over dead objects and ill-gotten gains.

Tristan Tzara, $1951^{2}$

\section{Introduction}

To wed Dada with ethics is to consummate incongruous and quarrelsome bedfellows. And yet, as early as 1920, the German academic and journalist Kurt Pinthus 'diagnosed' in his anthology Menschheitsdämmerung: Symphonie jüngster Dichtung ('Twilight of Humanity: A Symphony of the Most Recent Verse') a '"momentous turn toward the ethical [große Hinwendung zum Ethischen]" in the works of those responding to the upheavals of World War I and its aftermath. ${ }^{3}$ Furthermore, extending beyond the redrawn borders of a defeated Germany, poet Gottfried Benn suggested in his introduction to a later anthology Lyrik des expressionistischen Jahrzehnts, von den Wegbereitern bis zum Dada ('Lyrics of the Expressionist Decade: From Precursors to Dada') (1955), that there had also emerged a need for 'wirklichkeitszertrümmerung' (a 'reality-shattering') aesthetic. ${ }^{4}$ Poetry had undertaken the extraordinary task of reforming aesthetic practice, challenging the verisimilitudes of realism in response to epistemic and existential questions of value and being. The experimental 
innovations towards a new poesis, identified by Pinthus and Gottfried in the ethical turn of the early twentieth century, marked the radical response of avant-garde poets faced with the suffering precipitated by the total devastation and global upheavals of the world's first industrial war. Mass fratricide and widespread carnage unsettled the sedimented morality of scientific determinism, institutionalized religion, industrial, and historical progress, and wrought profound complexities on human socialization in the second decade of the twentieth century. At the same time, a new radicalized art poesis - experimental, multivalent, and transmodal - labelled 'Dada' and emboldened by a moral outrage, shocked the art-world from its ethical complacency. Spectacularly violating normalized parameters and excavating the dimensions of the aesthetic, Dada upturned the perspectives of mimetic naturalism with constructivist and anarcho-political agit-prop, exploring photo-montage, abstract collage, sound poetry, painting, portraiture, and sculpture. Whilst it resisted the possibilities of a collective moral code, it is the argument of this paper that Dada poesis profoundly attests to the ethical tension of language troubling humanity in a vital process of historical transformation.

The intellectual discourses of an avant-garde aesthetics evolved, during the transition from the nineteenth to the twentieth century, in co-construction with a new experience of humanism, that is, ethical obligations, delimited according to a singular responsibility rather than social expectations predicated upon a moral telos. Cross-weaving the frayed social fabric of a post-imperial world view was a renewed ethical commitment on the one hand, and an emergent scepticism towards a totalising universal ethics on the other. Tony Davies describes the experience as 'a concept and practice of the human that proceeds not - like Descartes' self-contemplative "I" or Kant's transcendental subjectivity - from a primary centered ego reaching out to know and seize the world, but from an irreducible "other", the not-I that defines me for myself. ${ }^{5}$ In Theorizing the Avant-Garde: Modernism, Expressionism, and the 
Problem of Postmodernity, Richard Murphy describes a Romantic conviction whereby the 'autonomous status' of art 'turns it into a transcendent repository of moral and spiritual values. ${ }^{6}$ At the same time, this conviction, as Stefan-Sebastian Maftei notes in his article, 'Between "critique" and propaganda: the critical self-understanding of art in the historical avant-garde, the case of Dada,' is found in the origins of an avant-garde art which, as in the view of the pre-socialist Olinde Rodrigues, 'had the power to affect its audience and to produce sensations that would ennoble thought as well as provide the energy for social change towards the common good. ${ }^{7}$ Ulrich Kinzel describes the paradigm shift: "the fin de siècle witnessed a transformation of the moral and political sciences into social sciences, which, together with an emerging aestheticism, provided a new discursive frame for a literary return to ethics. ${ }^{8}$

The manifestos and philosophical proclamations of Dada, beginning with Hugo Ball's 1916 recital in Zurich ('Dada is the heart of words,' he concluded, and 'the word, gentlemen, is a public concern of the first importance'9 ${ }^{9}$ often refer to a moral impetus. In Germany, faced with the political realities of the Weimar Republic shadowing the rubble of a collapsed Empire, the November Group of politically radical artists and architects led by Max Pechstein and Cesar Klein, for instance, declared their determination in 1918 to unify 'all revolutionaries of the spirit' towards 'the moral cultivation of a young, free Germany.'10 Similarly, at the height of an interwar realpolitik, the German Dada artist George Grosz reacted against a fundamentally classist, bourgeois 'moralism' which was pervading the art world, describing in distinct terms, 'the cloud wandering-tendencies of so-called sacred art which found meaning in cubes and the gothic, while the field commanders painted in blood. ${ }^{11}$ At the same time, poet Richard Huelsenbeck was equally damning observing a culture industry serving as 'moral safety valve' and 'compensatory phenomenon.' 12 
It was retrospectively, in 1951, however, that the poet Tristan Tzara wrote most explicitly that 'Dada was born of a moral need, an implacable will to achieve a moral absolute.' ${ }^{13}$ Born in Moldavia to parents of Jewish Romanian heritage, and later performing at Dada's Cabaret Voltaire in Zurich before re-locating to Paris in 1919, Tzara gained a panEuropean perspective. Observing the frayed social fabric of a western consciousness haunted by the unspeakable acts of genocide, he described the Enlightenment wasteland of modernity littered with 'notions emptied of all human substance,' of 'dead objects' and 'ill-gotten gains. ${ }^{14}$ Ambitious for an international art movement, as Leah Dickerman has suggested, Tzara had envisioned a 'proto-globalized identity.' 15 And yet, faced with the humanitarian atrocities of the First World War, Tzara also distrusted the possibility of a collective moral code: 'I have no confidence in justice,' he wrote in 1921, 'even if this justice is made by Dada.' ${ }^{16}$ As Huelsenbeck reflected, events at the Cabaret Voltaire had been a 'spontaneous aggressive activity, ${ }^{17}$ 'a violently moral reaction. ${ }^{18}$

Connected via its new media forms (the telegraph, picture postcard, telephone, typewriter, and magazine), Dada animated the metropolitan epicentres in Europe and North America. ${ }^{19}$ It thereby emerged as a transnational movement and, ultimately, a 'program against programs, an ethics of absolute freedom,' as Lawrence Rainey introduces Dada for his landmark Modernism: An Anthology (2005). ${ }^{20}$ Succeeding a one-issue periodical of the Cabaret Voltaire, the Dada journal, for example, functioned as a supranational network bringing together the Dada avant-garde to throw off the behavioural expectations of a moral telos, as Rainey suggests, in 'an intransigent denial of everything. ${ }^{21}$ Indeed, writing in April 1921 for the little magazine New York Dada, edited by Marcel Duchamp and Man Ray, Tzara had also proposed that 'Dada is neither a dogma, nor a school, but more a constellation of individuals and free facets." 22 Maftie's interpretation corresponds: "Dada is entirely negative to any affirmation, system or theory [...] the manifesto of Dada can be an anti-manifesto 
only. ${ }^{23}$ Thus, it is apparent that Dada's political commitment amounts to a negation of the very institution of art, to a nihilistic anti-aesthetic that abandons all textual meaning. ${ }^{24}$ As Raihan Kadri has observed, 'Dada is primarily known for its negation, its stripping away of values given to identity, both of people and of things. ${ }^{25}$ Within this interpretive frame, Dada is formulated to operate at the limit of a metaphysics, as described by Martin Heidegger in 'The Word of Nietzsche: "God is Dead,"' where 'Nihilism is the world-historical movement of the peoples of the earth who have been drawn into the power realm of the modern age. ${ }^{26}$

It is typical then to conclude that Dada's moral outrage is the source of a nihilistic anomie, but ethics is not simply a matter of delineating 'right' from 'wrong.' Rather the 'new ethical criticism,' as signalled by Laurence Buell in his introduction to a $P M L A$ special issue on 'Ethics and Literary Study' in 1999, works towards a phenomenological account of the 'textual body' as a philosophical meta-discourse on the process of signification between self and other in order to re-read the political and social possibilities of different literary forms and genres. ${ }^{27}$ Ethical critics are thus working through the philosophical inheritance of poststructuralist thinking (from Jacques Lacan and Mikhail Bahktin, to Emmanuel Levinas and Jacques Derrida) that bequeathed a complex notion of subjectivity, conditioned by language, and necessarily limited (split, traumatized, or de-centred). In that respect, both difficult and wilfully contradictory, rather than one-dimensionally nihilistic, the textual ethics of Dada, I propose, may be uniquely understood as a radical phenomenology of the subject that illuminates both the ethical tension of language and its affective capacity within the subject's traumatic relationship to the transformational ontological conditions in the first decades of the twentieth century.

Where a humanist ethics begins with ontology_, that is, 'being,' to construct a narrative of the self - an ego or identity that is the character of one's moral behaviour, and yet dependent in fact upon its contextualization within a set of cultural discourses - Dada 
focuses instead on the encounter between self and other. The avant-garde experimentation of Dada breaks from a naturalisation of the mimetic (and a meaning that inheres in language), in order to render split subjectivity decoupled from the master signifier that secures its morality. The encounter with the 'texterial' (or the materiality of the signifier) is of profound ethical importance for it is both a site of is symbiotic of the desire for the other, completeness, and the a play between identification and multiplicity (in Bakhtinian terms, the centrifugal and centripetal forces in language). Indeed, it is perhaps because of its ethical difficulty that Dada has become the forgotten experiment in America's early twentieth century emergence of an ethical poesis. For Dada ultimately conceived in the question of 'freedom' a dichotomy between anarchy and reason, as Tzara concluded his 1918 Dada manifesto: 'Freedom: Dada Dada Dada, a roaring of tense colours, and interlacing of opposites and of all contradictions, grotesques, inconsistencies: LIFE. ${ }^{28}$ Indeed, if Dada is taken to yield no universal moral truths then there is a comforting cognitive closure to its current art historical canonization; and yet, on the contrary, marrying it with the ethical, I propose, is central to Dada's textual play.

The challenging and original poesis of 'the first American Dada,' Baroness Elsa von Freytag-Loringhoven (1874-1927) (as she was named by publisher and editor Jane Heap in the June 1922 issue of The Little Review), ${ }^{29}$ provides a provocative instance of a poetry that gives creative expression to the moral realization of her modern subject. Best known for her sexually charged street performances, the German-born poet Baroness and artist appears as a composite in the central character of Robin Vote from Djuna Barnes's 1936 classic modernist novel, Nightwood. She is also the subject of a dramatic rise to critical acclaim challenging a canonical Euro-centric account of Dada, and fuelling debates on the history of women's poetry within literary modernism. ${ }^{30}$ Historically, the Baroness has become known as a figure of New York Dada; appearing in works by Man Ray and William Carlos Williams she was, 
as Barnes wrote in her unfinished biography, one of the 'characters, one of the terrors of the district. ${ }^{31}$ But formative in the Baroness's poetic oeuvre was the aestheticism of the 'George Kreis' ('George Circle') in Berlin, a coterie of younger men idolizing the German poet, editor, and translator, Stefan George their leader ('Herr Meister') within which the Baroness became well known (if feared for her sexual antics) from 1896 to $1898 .{ }^{32}$ As Ulrich Kinzel has shown, quoting the famous poem 'Secret Germany,' George's poetry created 'a new space in the old' as he 'rework[ed] poetry into an operator for a return to ethics and to an ethical community. ${ }^{33}$ George's two-fold poetic strategy combines what Kinzel terms the 'erotic' as a 'constellation of self, wholeness, and sovereignty undermined by sacrifice, ${ }^{34}$ in an ethics of form, as Edith Landmann reads George - embodying its content 'to convert it into a law ${ }^{, 35}$ - in order to create his new ethical community. Through the 'George Circle,' the Baroness thus had early exposure to an ethical poetics, a root for her radical aesthetic experimentation in stirring up the New York avant-garde scene. Vital, then, to an understanding both of Dada's textual ethics and, within this, its international context, the Baroness is a trans-continental figure; she mixes the European moral imperative at the fin-desiècle - its anti-bourgeois counter-cultural radicalism and high-minded aesthetic stylization with New York Dada's ‘ethics of absolute freedom' (in Rainsford's terms) and playful selfintrospection.

Insofar as Dada art practice is not an 'ism' it resists lapsing into meaning, into the totalizing, or moralizing, agency of the 'said,' that which assumes interpersonal, corporate, or cultural agency as a hermetically sealed and transferable unit of rested meaning. In an artworld with a distinctly patriarchal bias, the Baroness, furthermore, is the irreducible stutter in da-da's literary history. But what makes her poetry an enlightening paradox for ethical criticism is that it is also profoundly limited by the extreme form of its 'traumatized semiotics,' as John Wrighton-I have define $\underline{\text { ds }}$ it elsewhere, 'where individuals are bereft of a 
language sufficiently responsive in the face of suffering. ${ }^{36}$ 'Trauma [...] is a component part of modernity and of those forms through which we both inhabit and encounter its history,' Lisa Sultzman and Eric Rosenberg have argued. ${ }^{37}$ Indeed, trauma is nowhere more apparent than in the troubled subjectivities of the Baroness's poetry which bears witness to the neurasthenic effects of the First World War; as identified by Amelia Jones, they appear 'as a complex network of bodily/psychic symptoms that rupture the subject's smooth functioning. 38

Adapting Tzara's earlier pronouncement, Dickerman has argued that 'Dada was born of a moment of moral and intellectual crisis, poised between the disaster of war and the shock of an emerging modern media culture. ${ }^{39}$ Yet the Baroness's Dada poetry reveals how 'being' is a product of signification and de-naturalises media culture's claim to a constitutive freedom. Holding open the mimetic as if it were a sprung trap, the Baroness obliges her reader to respond (and responsibility) to and take responsibility for her naked words. Illuminating the passionate working through of an ethics of poetic form in its 'texterial' subjectivities, the following reading also demonstrates how the Baroness's poetics paradoxically embodies Dada's ethical limit. For whilst her formal experimentation strives to create an ethical unity between text and reader - a completeness in the self-other relation, or intersubjectivity - her poetics cannot resist either the ontological limits of its identitythinking, or the postwar trauma of its modern and fractured (non-)self-identity. In these limits of being then, the Baroness, is the preeminent example of the textual ethics of Dada.

\section{Dada Poesis and the Temporality of Trauma}

The Baroness developed her poetic oeuvre during one of the deadliest conflicts in human history. It is against such fear (a temporalisation in the linear progress of mortality, exacerbated by the First World War) that she put forth her poetic experimentation even as she 
was filled with 'suicidal fantasies. ${ }^{40}$ In the aptly-titled posthumous collection of her poetry, Body Sweats: The Uncensored Writings of Elsa von Freytag-Loringhoven (2011), the Baroness describes her self in a poem entitled 'Constitution':

\author{
Still \\ Shape distinct - \\ Resist \\ I \\ Automatonguts \\ Rotating appetite - \\ Upbear against \\ Insensate systems $(B S, 171)$
}

The lyric subject begins in this opening stanza of 'Constitution' in a state of self-contentment and ontological stability, but is soon set against the automation of new 'insensate systems.' The speaker strives to “"Keep smiling!"'/ Act - act - act - act -/ Go on - on - on - onnnnnn ' until, in the third stanza, 'nervetransfixion/ Fatally touch/ fibrous mould' $(B S, 172)$. The conflation of 'nerve' and 'transfixion' marks a change from the inside outwards, a wondrous terror sensed through a temporal caesura, and a piercing of the speaker's sense of self. As Friedrich Nietzsche reasoned in his essay 'On Self-Overcoming,' 'whoever must be a creator in good and evil, verily, he must first be an annihilator and break values, ${ }^{41}$ a sentiment echoed in the line, 'Selferecting - annihilating' $(B S, 172)$. Interrupting the narrative or progressive linearity of character, 'Constitution' gives creative expression to an assault on the nervous system interrupting the relations of time and space; in the electro-shock of this internalized trauma, the moral capacity and ethical infrastructure of the self is re-moulded. In the hope of aesthetic and ethical redemption the Baroness folds into her poetry a transformative personhood in the posterity of a being otherwise. Indeed, she often seems to 
be writing the poetic subjecthood not only of that perceived in her by her contemporary peers, but that which will be reconfigured in a future readership (after her death). The trauma of this poetic temporality, and its dialectic relation to the First World War, is articulated in her poem 'Perspective' $(B S, 264)$ which begins:

\author{
In Latin France. Massive Roman shell \\ Crystallized incandescent luminar \\ Onto sunproximity. \\ Post potency Bridal's rape-finale - - \\ Transparency condensing clay preparatory
}

An opaque poem, 'Perspective' moves between multiple time frames and locales of interpretation. It opens in a demilitarized field in France in the years after the First World War with the image of a bomb crater ('Massive Roman shell'). Folded into this image is the weight of the past as registered in the language (Latin) and the imperial might of Rome as centres of political and cultural power. The historical blast as flash-back (perhaps of a Mills bomb which has a serrated edge and so fragments on detonation) creates a white-out in the electro-shock: 'Crystallized incandescent luminar/ Onto sunproximity.' As Walter Kalaidjian defines the experience of trauma, a complex 'future anterior' 42 enters with the violent line 'Post potency Bridal's rape-finale,' capturing the sense of being after the promise of something which is yet to come. By bringing the opaque into focus, the Baroness's poetry performs the act of linguistic representation, as words are moulded into cultural meaning. On the other hand, by holding the reader in the moment before meaning emerges, the poetic form of the line cannot yet be read, it is an ethical subjectivity in prolepsis, the very diastasis of identity described in 'Perspective' as 'Transparency condensing clay preparatory.'

As a poem about her critical reception across the avant-garde circles of Europe and America, 'Perspective' also envisages what Gammel has described as New York Dada's 
'unprecedented ferment of American and European cross-fertilization in art. ${ }^{43}$ The poem concludes:

\author{
In new continent stands Heir \\ Receptacle elect.
}

\author{
Betwixt her nimbused form America's \\ Womb cluttered - — shaping hulk — \\ Relations of mutual esteem \\ Forecast event. $(B S, 264)$
}

The post-war 'Relations of mutual esteem' marks the Baroness's attempt to bring new energy and movement to America's influence as a 'shaping hulk' and to 'Forecast event' of an ethics resistant to the foreclosure of its signification.

In addition to the trauma of mortality in the Baroness's poetic subjectivity, there is a further element that registers in the subtext of 'Perspective.' Alongside the emergence of a social science and in response to an upsurge of emigration (particularly to America's cities) Adam McKible points out that there also developed 'a wide range of pseudo-sciences dedicated to establishing and codifying racial differences and hierarchies. ${ }^{, 44}$ The Baroness was not immune to such reactionary cultural stereotyping and a Teutonic superiority fuels the anti-Semitism in her poetry as she seeks to sanitize her 'being' against foreign invasion. This fear comes to the surface, for example, in her prose poem 'The Modest Woman' where she mixes sexual sterility with a racialised body in order to defend her 'aristocratic public' ( $B S$, 288). In describing the 'vulgar/ untrained brain' of an American who 'Eats stupidly also' (BS, 286, 287), the Baroness has interpellated what Christopher Breu refers to as 'the fetishized grid of the socially dominant symbolic,' the ideological discourses 'organizing our social relationships of race, gender, and sexuality. ${ }^{45}$ However, in contradistinction to a reflective 
contemplation, 'Perspective' effectively challenges a social ordering of the status quo, not simply by way of a nonconformist Dada play, but uniquely in the textual performance of a lyric subject both multiply located and temporally diffuse. Whilst the Baroness's 'The Modest Woman' has overtones of the anti-Semitic, her poetry nonetheless provocatively invokes, and perhaps intentionally upsets, ethno-racial and sexual determinations.

When Kurt Pinthus diagnosed a 'momentous turn toward the ethical, ${ }^{46}$ he understood that Dada was a working through of the trauma of that era. The Baroness's poem 'Perspective' performs the configuration of history and subjectivity, attentive both to competing individual and national identities, in a way that challenges ethical norms and social expectations. As Peter Middleton argues, Indeed, the meaning of a poem is not limited to the original said text, but accrues cultural value across the distances of its reception. ${ }^{47}$ In this respect, it can be proleptic of new modes of being, or being otherwise, and is open to the approach of the other. The singularity of the Baroness's poetry is that it does not take its own interiority as the totality of its meaning. As Derek Attridge has explained of poetry's 'distinctiveness,' 'what is performed is not just a linear sequence of specific words, but their happening in an experience of temporality. ${ }^{48}$ The Baroness's 'Perspective,' then, is conditioned by the trauma of the 'Real,' to take the terms of Jacques Lacan - opposed by the 'Imaginary,' exterior to the 'Symbolic,' and against which 'all categories fail'49 - but, with the intention of becoming, as Attridge admits of the 'singularity of literature,' 'inventive in its difference.' $^{50}$

\section{'Texterial' Dada and the Body}

In the move towards a textual ethics of Dada, the Baroness's writing pushes at the limits of artistic practice by crossing the boundaries of genre in poetry, sculpture, drawing, posing and performances, in order to create a radical poesis lived in (and on) the body. The desire for an 
ethical redemption through a public aesthetic is further evident, for example, in the Baroness's street performances. In the many anecdotal, documentary, and biographic descriptions of her performance art, the everyday objects of the Baroness's exotic costumes are always shown to have been painstakingly (perhaps lovingly) prepared and presented. Margaret Anderson describes the Baroness's first visit to the office of The Little Review: 'She wore a red Scotch plaid suit with a kilt $[\ldots]$ ten-cent-store bracelets $[\ldots]$ high white spats $[\ldots]$ a black velvet tam o'shanter with a feather and several spoons. ${ }^{51}$ Appropriating the quotidian objects of the working class and re-using them within the dramatic presentation of her avantgarde art, the Baroness demonstrates how these objects are not merely 'pure things' but constitutive of being, active signifiers in interpersonal discourse. As Alex Goody has argued, 'her use of commodity objects [...] produces the body as an assemblage of prosthetic components. ${ }^{52}$ Indeed, there is a special care in her performances and a self-reflexivity in her representations and codifications where even everyday activities were to the Baroness moments to be transformed for the ecstasies of art. These 'things' become part of complexly constructed art-costumes, cleaving to her body an ethical phenomenology that does not transcend its material essence.

A cross-genre, experimental ethics is also found in the Baroness's letter writing. In her largely unpublished correspondence - each of her letters average ten or so pages in length, with the longest extending to thirty-five pages - she would produce four or five drafts of a letter suggesting that it was a form of art to be perfected, rather than a mere method of communication. Careful analysis of an original manuscript letter written in Paris to her American friend Sarah Freedman in the spring of 1927, with bi-focal attention to both its form and content, reveals a startling poesis. Like many avant-garde artists the Baroness recycled material resources for her writing so as to save expending a meagre income, but the choices of material are also central to her work. By piecing back together the pages of the 
letter, it becomes evident that the Baroness has torn up one large (or possibly three or four smaller) used art canvases on which appear sketches of anatomy, into legal-sized paper - a hand (fig. 1) and upper arm (fig. 2) - and full drawings of nudes (fig. 3 and fig. 4) - and then proceeded to write over the top of the sketches.

Hand-written and capitalized in her signature, deeply-engraved calligraphy, each draft is a performance of her subjectivity in its corporeal materialization as textual body. The letter to Freedman is an example of the extreme tensions that are stretched out across hyphenated clausal units in the Baroness's lean body of work. Cut to the bone in its minimalist resistance to clutter - the saturated fats of bourgeois consumption - but sinuous in its muscular physicality, the Baroness's writing follows the form of her figure. The singularity of its literary affect is emblematic of that theorized by Alex Houen, 'a kind of feedback that borders on performativity,' and which involves 'emotional compounds of bodily feeling and cognition. ${ }^{53}$ For in the textual ethics of this letter is a series of tensions between identity, personality, character, socialization, language, sign, calligraphy, literary affect, and reader reception. At the level of calligraphic choice, for example, the Baroness's writing illustrates what Simon Jarvis describes in pursuing an aesthetics of typography: 'how feelings get done in language - the "affectivity" of language "performances" - travels right through to the very serifs, uprights and swashes of its written, printed, drawn or carved or painted letter forms. ${ }^{54}$ The forcible angularity of her hand-writing both corresponds to the rigidity of meaning and contrasts with the fluidity of the body, registering within her address what Breu has described (of 'transgressive postmodernism, ${ }^{, 55}$ suggesting that the Baroness's work preempts a later twentieth century experimentation), as 'the ineluctability of material embodiment and the flesh of being. ${ }^{56}$ In performing the textual body, the Baroness seeks to transcend that which delimits the ethical potential of art, that is, the non-transference of meaning between text and reader. 
In preparing the letter to Freedman, rending the canvas(es) into page-size sheets does not so much disfigure or anatomize the sketches as create a gymnastic dramaturgy of limbs and gestures of movement, an act of performance in prelude to a deeply-engraved writingover of those limbs as body spaces for the Baroness's address. Overall the letter thereby challenges the reader's kinesthetic sense of proprioception - stressing the parietal cortex of the brain by presenting conflicting information regarding the positioning of parts of the body. This achieves the possibility of an ethical re-orientation in a process described by Melba Cuddy-Keane: 'the body's nonconscious strategies for spatial navigation activate similar schema for the navigation of mental space. Bodies may instigate shifts between way-finding strategies, enabling cognitive change. ${ }^{57}$ Over and above an act of communication, prior to, as exceeding its interpretable meaning, the intersubjective experience of the Baroness's Dada is to create a unique 'texterial' ethics.

The act of correspondence for the Baroness - from the initial posing and sketches, the rending of the canvas, the calligraphic over-writing, the delivery and reading (or spatial navigation) - is a performance that maintains the diastasis of identity; it gives shades of light and dark and contours to an otherwise flat address, transforming the letter into a primordial donation in the vital kinesis of the body. ${ }^{58}$ As with the poems 'Constitution' and 'Perspective,' the Baroness's letter thus also has a poesis, breaking from the past and challenging the reader to come to terms with, or to explore, the cognitive, perceptual, and personal demands of being. By performing the textual body the Baroness's poetics throws a conventional linear reading practice into disarray, challenging the reader to navigate bodies as a textual work beyond the evaluative mode of a neo-humanist moral telos; offering instead, 'embodied cognition, ${ }^{59}$ or new modes of being through a lived Dada aesthetic. Reading the letters is thus to find oneself obligated to witness before their very form; as the Baroness 
wrote in a letter dated August 29, 1927, to the wealthy art collector Peggy Guggenheim, 'now I gather form again - conceive anew. $<$ This letter - what it reveals - bears evidence $>{ }^{60}$

The emphasis on a vital kinesis of the body is also entirely appropriate for the purpose of the earlier letter to Freedman which opens with congratulations on the arrival of her newborn baby. Delighting in the wonder of child-birth and the creative-destructive pain of living in general, the letter, after a lengthy self-pitying, however, turns to a plea for (financial) support:

I nearly did break — shattered to unrecognizableness — to mineownself $[\ldots]$ to relieve pain in creation - since pain of destruction in this life is uncreative! But — I rallied — since still I am in life [...] Sarah — help me! It is easily done - it is no risk. ${ }^{61}$

There is an intentional, if strange, contradiction between 'unrecognizableness,' where the Baroness's face has blurred from public view (or perhaps merged into its environment, like the woman in Pablo Picasso's $193 \underline{2} \theta$ portrait, Grand Naked Red ChairNude Woman in a Red

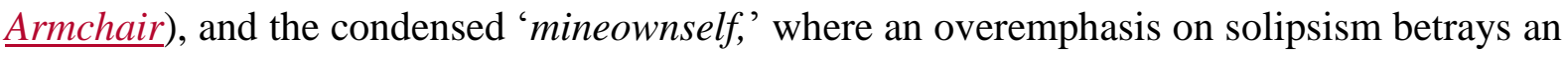
isolation threatening her 'imagined' ontological presence and identity-thinking. The Baroness's plea for help concludes that 'it is no risk' for Freedman since her help could be discrete from opposing social expectations, from a moral telos, for instance, where such an improper character as the Baroness would be kept at a distance. In the letter to Freedman, a remarkable articulation of the self and its interdependence with the other is also tied to the project of the Baroness's art as she wilfully determines to press onwards as against the deathdrive of nihilism, for 'destruction in this life is uncreative!' The overall poesis involved in the material production of the letter as a 'texterial' poetics of the body is thus the Baroness's ethical appeal to the reader, a plea for financial - and ontological - support. In the Baroness's 
presentation there registers the ethical tension of language: a subjectivity speaking, or stuttering, an ethical saying that threatens the limits of a wilful identity-thinking.

\section{Dada and Desire for the Other}

In her 1927 letter to Freedman, the Baroness claims to care little for the 'niceties of human intercourse, ${ }^{, 62}$ but her lifestyle - so keenly devoted to her art - is fused nonetheless with a desperate suffering, abuse, and loneliness, living after the War as an impoverished artist between the cities of New York, Berlin, and Paris. Her loneliness and desperation (she died of gas asphyxiation - a probable, though inconclusive, suicide - in December of that year) adds to the intensity of an already radical poesis which condenses multiple signifiers and vignettes into vertical series of short affective units. The recurring thematics of the Baroness's poetry are the intimate emotions of lust, desire, and mortality, expressed in a language and religious imagery that moves deftly between the interpersonal relations of empathy and power. Her 1922 poem 'Lullaby' typifies these poetic concerns in her condensed and minimalist form as the words run down the side of the page and are paired and arranged into stanzas of two, three, or six lines which juxtapose and antagonize fixed meanings. Perhaps as a way to break the homoeroticism of the avant-garde's closed groups, common to many of the Baroness's poems is her obsession with sex and orgasm: 'Ultimate/ Orgasm/ Supreme' and 'Act -/ Orgasm -/ Death finale - - -' she writes in 'Lullaby' (BS, 203). Dada, of course, revels in the upsetting of sexual taboos and gender play, but for the Baroness the sexual (self-) expression in 'Lullaby' is an aggressive addiction before it is a liberation of being, originating perhaps, as the title of the poem suggests, from an abusive and unresolved childhood.

The interpersonal relations of being also appear in the Baroness's more politically expansive poems. 'Cathedral' (BS, 61), first published in the Little Review in 1920, eschews 
'art appreciation' in a jarring exhibition of expectant provocation. The poem begins with the accusatory opening two lines, 'Why didst thou go away from me?/ Say - why?' which even forgiving their petulance, leave the reader, having only just approached the poem, very little room for manoeuvre especially in the abruptness of the second line - the 'why?' that is thrown directly off the page and into the reader's gaze. The question gives immediacy to the Baroness's persona which presses in on the poetic language a vulnerability, insecurity, and tearing pain, whilst at the same time establishing the central thematic concern of her poetic oeuvre bringing the reader into the dynamic tension of self-other relations, that is, the textual encounter or face-to-face of language in art. ${ }^{63}$

The opening emphasis in 'Cathedral' is on the optical distance of a subject and object competing for the position of voyeur, but 'not by mine lips - so softly passionate/ so passionately soft' shifts the cognitive faculties towards the intimate tactility of lips touching. The caress holds in balance the selfish desire to consume the other and a selfless desire of care for the other in the alternating of 'softly passionate' and 'passionately soft.' Such feelings of course can be a 'harnessed strength' or a 'bridled strain' enabling as much as they are disabling (or disarming?) of the individual. Prognosticative of an ethical experimentation in poetry of the late twentieth century, the Baroness herself might have theorized, in the words of the 'Language' poet Bruce Andrews in his poetics book, Paradise and Method: Poetics and Praxis: '[the poetry allows] desire to register as a kind of community-building,' 'not a production so much as a constitution of desires [...] not a representation, but an articulation of and on the body.' 64

In 'Cathedral,' opthalmoception (sight) and tactioception (touch), the cognitive faculties work together in the combined colours and scents of 'musk - amber - myrrh and frankincense -/ gold - damask - ivory - ' in a crescendo that rises to the line 'mine gothic cathedràl.' But the speaker ultimately finds herself alone and the phallic connotation in the 
flaccid disappointment 'is that upbuild in vain/ for thee - ?' becomes a searching, and posterity - 'the whom I shall desire -/ to pray?' The poet longs for attention as the poem longs for an audience, a 'worshipper' and 'devotee.' 'Thus stand I desolate - ' writes the Baroness, her syntax reversing 'stand' and 'I' to give a grandiose emphasis on the ego and a melodrama to her desolation, 'priest to mine tarnished self.' There is a self-pitying in the human isolation, but also a knowledge that art is not ephemeral; it lives on even after death in a world where 'light tapers stately - upon jadeworsted shelf/ not to decay.'

'Cathedral' is not delimited, however, by the negotiation of the pure ontological structure of an interpersonal subjectivity, but instead folded into the subject persona is the social context of its history, religion, and culture. Though the Baroness wrote the poem whilst she was living in Greenwich Village in 1920, the choice of the signifying cathedral reminds us of her European heritage. But the Baroness's poetry also has a complex relationship with the matrices of different national audiences, and the trans-continental perspective introduces a complex doubling to the poetic voice. In 'Cathedral,' the Baroness plays on this diastasis of identity through an extended emphasis on the otherness of 'mine gothic cathedràl.' The use of the accent grave encourages the reader to stress the vowel sound at the diacritical mark, building both a resonance and othering of the poetic voice of the poem.

The textual ethics of 'Cathedral' are further complicated as the poem opens up to its multiple dimensions (much like a cathedral will have transepts, aisles, cloisters, and nave), and there is a frequent flipping of dual meanings, not so much an oscillation in and out of referential focus as a semantic whiplash. The opening refrain, 'art not enslaved by balmy wizardry/ out of mine jeweled eye,' on the one hand, describes an art form not enslaved to (professional) expertise, divination (that is, fixed meaning), or sorcery (trickery or fakery), all of which are synonymous with the description of a - curiously 'balmy' - 'wizardry.' On the other hand, the refrain questions whether the reader/lover is in fact enslaved by the seductive 
and playful sorcery of the speaker's sparkling eyes. The ingenious dual meaning, with a pun on the word 'art' and ellipsis of the word 'thou,' complexly imbricates the 'person' of the Baroness and her art work, collapsing the two together into her unique performativity.

The Baroness's poem 'Cathedral' opens a liminal space of defamiliarity in its Dada poesis marking the beginnings of a new avant-garde experimentation in early twentiethcentury poetries preoccupied with the socialization and intimate and ethical relations between self and other. It is the extraordinary personal dejection of the Baroness as poet-subject here, a radical provocation in difference that must be met by the gaze of the reader-subject. But it is also a new aesthetic by which the spatial place of the poem becomes a dynamic architecture of ontological possibilities. Dickerman describes Dada poetics as 'a refusal to "stay at a distance," a refusal both of transcendence and sublimation. ${ }^{95}$ Thus Dada poetics, on the one hand, draws the reader into an active relationship with textual meaning; as in the poem 'Cathedral,' the reader is seduced into an intimate proximity with the other. On the other hand, Dada operates by textual expulsion, and the reader is aggressively rejected; as Walter Benjamin writes in his essay, 'The Work of Art in the Age of Mechanical Reproduction,' Dada functioned as 'an instrument of ballistics. It hit the spectator like a bullet, it happened to him, thus acquiring a tactile quality. ${ }^{66}$ The literary affect (which Benjamin's description militarizes) is thus generally one, in Dickerman's terms, either of 'outrage or conspiratorial laughter' ${ }^{67}$ - as might be provoked by the sexualized religious imagery in 'Cathedral' - but as the Baroness's poem illustrates, it also profoundly invokes the question of the ethics of reading.

Robert Eaglestone argues that the compulsion of an ethical responsibility registers in the search to define a so-called 'new aestheticism,' a 'noninstrumental "location" of truth,' found in the singularity of the artwork, its 'unique world-disclosing capacity,' that is, an aletheia or uncovering. ${ }^{68}$ The peculiar singularity of the companion piece to the written poem 
'Cathedral' (fig. 5), an eleven inch mounted wood fragment or found object (objet trouvé) by the Baroness, necessitates this uncovering as it reveals multiple subject positions in international relations: it can be read alternately as modelling the towering skyscrapers rising up into twentieth century New York City, as the gothic spires of Europe's timeworn cathedrals, or simply as a piece of driftwood, a castoff remnant used as material figurative of the wood from the ship of the first pioneers to the New World. Furthermore, Eaglestone defines aletheia as defamiliarising, and this defamiliarising may be seen in the radical, committed aspect of a Dada poesis, specifically where the Baroness's playful and shocking abrasiveness uncovers different possibilities or modes of being.

In the pivotal question of her 'Cathedral' poem - 'art not enslaved by balmy wizardry/ out of mine jeweled eye' $(B S, 61)$ - is the hope for an ethical representation in art that resists an overt interpretation and thereby easy consumption, in favour of an attentive responsibility. Yet this poem also exhibits the ethical limits of Dada for its focus is the identity-thinking of the lyric construct, a (self-)representation that attempts to fix the gaze of the reader. There is a further instructive parallel here with Stefan George's poetic career, as Kinzel argues, 'the poet's self-fashioning [...] is an act of self-empowerment,' a critique that might well be applied to the Baroness, who arguably was also engaged in 'a desperate effort to people an empty fortress. ${ }^{69}$ The trauma in the existence of being - in mortality, war, and social exclusion - forever haunts the Baroness and motivates her increasingly extreme and dramatic performances of a divided personality. A profound confusion as she struggles to locate what is most central to inter-human subjectivity appears most forcefully in her poem, simply entitled, 'Atom' $(B S, 90)$. 'Atom' asks the existential question, what constitutes being? In so doing it locates the navel, rather than the unique presence of the face, as the centre of the body. A primordial urge to procreate, a selfish lust and longing for sexual consummation, an essential need to satisfy the appetite of the stomach, all these are tied into the navel and the 
temporality of a narrative telos, 'each/ sun faced/ little/ clock.' In 'Atom,' ontology is centred before the ethical, exhibiting what the ethical philosopher Emmanuel Levinas describes as, 'an ego assimilating the other in its identity, and coiling over itself [...] enjoying its own appetite. ${ }^{70}$ In psychoanalytic terms, as Calum Neill explains in Lacanian Ethics and the Assumption of Subjectivity, 'the subject is always (being) constituted in relation to the Other and, in particular, in relation to the desire of/for the Other. ${ }^{71}$ Pushing at the edges of the ontological, it is the Baroness's desire to hold open this dynamic as an emancipatory activism in art and an ethical experimentation that motivates the multiple dimensions of her Dada practice. Nonetheless, there is an awful sense of despair in her poetry that is rooted in a poesis at the limit of (her) being. As she wrote to Peggy Guggenheim, bemoaning her dejection: 'Thus again - was I left chilly bereft - stripped of any one - cherishing some previous conception of $m e .{ }^{, 72}$

\section{Conclusion}

In Tzara's words, and notwithstanding its playful impugnation, 'Dada was born of a moral need, ${ }^{, 7}$ its aesthetic a response to the ontological traumas of the early twentieth century. But the Baroness's avant-garde experimentation in poetics - with its multi-dimensional temporality, erotic performance of self-other relations, and 'texterial' body - advances the possibility for the textual ethics of Dada. Uniquely, the Baroness's poetry brings the reader into an uncomfortable proximity with a 'textual body' that is multifold - a highly charged signification of intimacy and desire across page-space and body surface - beyond the normative boundaries or interpretive spheres of textual meaning. Opening a space which is polymorphous rather than synthetic and rigid in its interpretable meaning, the texture of her Dada poesis attests to an ethical saying in the process of its signification. 
Despite the responsibility of ethics to the other, the Baroness turns inwards to the limits of being in a poem, simply titled, 'Perpetuity' $(B S, 291)$. Her pain finds bleak expression in this poem with its imagery of cannibalism and the dark night of the soul. In the Hollywood dream factory words are cheap and codified at 'Checkless expense'; 'monotonous reels' pacify us in the 'switch/ Of:/ Sleep - love - pain - ' such that the Baroness can find no reason to become 'Involved.' It is the agony of human isolation, the faceless anonymity of rejection - 'Agony/ Anon' - that leaves the reader here with a 'Chill,' a 'White shriveled heart.'

${ }^{1}$ Elsa von Freytag-Loringhoven, 'Letter to Sarah Freedman' (n.d., 1927). Series 2, Box 1, Folder 15 (Elsa von Freytag-Loringhoven papers, Special Collections, University of Maryland Libraries). This research greatly benefited from access to the resources of the Modern Literature and Culture Research Centre (http://mlc.ryerson.ca/) at Ryerson University, Toronto, and the article was prepared with funds provided by the Canada $\underline{\text { Research Chairs program. I am grateful to Dr. Irene Gammel for first introducing me to the }}$ Baroness's startling body of work.

2 Tristan Tzara, 'An Introduction to Dada', in The Dada Painters and Poets: An Anthology, ed. Robert Motherwell (1951; Boston: G. K. Hall, 1981), 394.

${ }^{3}$ Michael Eskin, 'Introduction: The Double “Turn” to Ethics and Literature?' Poetics Today, 25:4 (2004), 559. Quoting Kurt Pinthus, ed., Menschheitsdämmerung: Symphonie jüngster Dichtung (Berlin: Rohwolt, 1920), xii. 
${ }^{4}$ Gottfried Benn, ed., Lyrik des expressionistischen Jahrzehnts, von den Wegbereitern bis zum Dada (Wiesbaden: Limes, 1955), 11.

${ }^{5}$ Tony Davies, Humanism (New York: Routledge, 1997), 132.

6 Richard Murphy, Theorizing the Avant-Garde: Modernism, Expressionism, and the Problem of Postmodernity (Cambridge: Cambridge University Press, 1999), 36.

7 Stefan-Sebastian Maftei, 'Between "Critique" and Propaganda: The Critical SelfUnderstanding of Art in the Historical Avant-Garde. The Case of Dada', Journal for the Study of Religions and Ideologies, 9:27 (2010), 220.

${ }^{8}$ Ulrich Kinzell, 'Configuration and Government: Stefan George's The Star of the Covenant', Poetics Today, 25:1 (2004), 732.

9 Hugo Ball, 'Dada Manifesto' (1916), in Flight Out of Time: A Dada Diary by Hugo Ball, ed. John Elderfield (Berkeley: University of California Press, 1996), 221.

10 ‘The November Group Manifesto’ (1918), in The Weimar Republic Sourcebook, ed. Anton Kaes, Martin Jay, and Edward Dimendberg (Berkeley: University of California Press, 1995), 477.

11 George Grosz, 'Abwicklung', Das Kunstblatt, 8:2 (1924); cited in Beth Irwin Lewis, George Grosz: Art and Politics in the Weimar Republic (1971; Princeton: Princeton University Press, 1991), 53.

12 Richard Huelsenbeck, 'En Avant Dada: A History of Dadaism' (1920), in The Dada Painters and Poets, ed. Motherwell, 43.

${ }^{13}$ Tzara, 'Introduction to Dada', 394.

${ }^{14}$ Ibid.

${ }^{15}$ Leah Dickerman, 'Introduction', in Dada: Zurich, Berlin, Hannover, Cologne, New York, Paris, eds, Dorothea Dietrich, Brigid Doherty, Sabine Kabriel and Leah Dickerman (Washington: National Gallery of Art, 2008), 1. 
16 Tristan Tzara, Oeuvres completes, vol. 1 (1912-24), ed. Henri Béhar (Paris: Flammarion, 1975), 574.

${ }^{17}$ Richard Huelsenbeck, 'The Case of Dada', in Memoirs of a Dada Drummer (1969), ed. Hans J. Kleinschmidt, trans. Joachim Neugroschel (Berkeley: University of California Press, 1991), 137.

${ }^{18}$ Richard Huelsenbeck, 'Dada, or the Meaning of Chaos', Studio International, 183:940 (January 1972), 28.

19 The city experience became central to Dada poetics. In the introduction to their anthology, Burning City: Poems of Metropolitan Modernity (Indiana: Action Books, 2012), Jed Rasula and Tim Conley observe that 'the city is the prism which reveals the full range of the spectrum within the same slant of light' (xiv). With more than four hundred poems, over five hundred plus pages, Burning City includes many of the Dada city texts in its 'flying tour' (xvii) of the 'international cross-fertilization of urban modernism' (xvi).

${ }^{20}$ Lawrence Rainey, ed. Modernism: An Anthology (Oxford: Blackwell Publishing Ltd., 2005), 461.

${ }^{21}$ Ibid.

${ }^{22}$ Tristan Tzara, 'New York Dada', in New York Dada, eds, Marcel Duchamp and Man Ray (April 1921). A facsimile reproduction of the magazine appears in The Dada Painters and Poets, ed. Motherwell, 214-18.

${ }^{23}$ Maftei, 'Between "Critique” and Propaganda', 222.

24 This is to understand the operation of 'nihilism' as formulated in Will Slocombe's historical account: "whereas "nothing" denotes an abstract concept, "nihilism" signifies “nothing” within an ideological framework.' See Will Slocombe, Nihilism and the Sublime Postmodern: The (Hi)Story of a Difficult Relationship from Romanticism to Postmodernism (New York \& London: Routledge, 2006), 3. 
${ }^{25}$ Raihan Kadri, 'Dadaist Poker: The Body and the Reformation of Form,' in Dada and Beyond: Vol. 1, Dada Discourses, eds, Elza Adamowicz and Eric Robertson (New York: Rodopi, 2011), 145.

${ }^{26}$ Martin Heidegger, 'The Word of Nietzsche: "God is Dead", in The Question Concerning Technology and Other Essays, trans. by William Lovitt (New York: Garland Press, 1978), 63. ${ }^{27}$ See Lawrence Buell, 'In Pursuit of Ethics', Ethics and Literary Study, PMLA, 114 (1999), 7.

28 Tristan Tzara, 'Dada Manifesto' (1918), in Dadas on Art, ed. L. R. Lippard (New Jersey: Prentice-Hall, 1971), 20.

${ }^{29}$ Jane Heap, 'Dada', The Little Review, 8 (1922), 46.

${ }^{30}$ Notorious amongst her avant-garde peers, but largely unpublished during her lifetime except for avant-garde periodicals, the Baroness is described by Robert Reiss as 'the embodiment of Dada' in his article "'My Baroness": Else von Freytag-Loringhoven', Dada/Surrealism, 14 (1985), 89. In 1992, her autobiography, Baroness Elsa (Ottawa: Oberon Press), based on a previously unpublished autobiography manuscript and letters, is edited by Paul Hjartarson and Douglass Spettigue. However, it is the new scholarship in avant-garde studies that has bequeathed the Baroness her most significant critics; a number of essays exclusive to the Baroness were published beginning in the 1990s by critics Irene Gammel, including a cultural biography, Baroness Elsa: Gender, Dada, and Everyday Modernity (Cambridge: MIT Press, 2002); Amelia Jones, including her monograph on the Baroness entitled, Irrational Modernism: A Neurasthenic History of New York Dada (Cambridge: MIT Press, 2005); Rudolf Kuenzli, 'Baroness Elsa von Freytag-Loringhoven and New York Dada', in Women in Dada: Essays on Sex, Gender, and Identity, ed. Naomi Sawelson-Gorse (1998; Cambridge: MIT Press, 2001), 442-77. The Baroness's poetry is open to an increasing audience: in May-June 2011, a special feature of the online poetics magazine, Jacket2, was 
dedicated to the Baroness; a digital collection of her poetry, In Transition: Selected Poems by the Baroness Elsa von Freytag-Loringhoven, is published online by University of Maryland Libraries and edited by Tanya Clement; Body Sweats: The Uncensored Writings of Elsa von Freytag-Loringhoven (Cambridge: MIT Press, 2011) is edited by Irene Gammel and Suzanne Zelazo (hereafter cited in text as $B S$ ).

31 Djuna Barnes, 'Baroness Elsa', 3 Waverly Place New York City (Elsa von FreytagLoringhoven Papers, College Park Libraries, University of Maryland), 1.

${ }^{32}$ For a detailed account of this period in her life, see Gammel, Baroness Elsa: Gender, Dada, and Everyday Modernity - A Cultural Biography, 73-89.

${ }^{33}$ Kinzel, 'Configuration and Government', 732, 749.

${ }^{34}$ Ibid, 738.

${ }^{35}$ Edith Landmann, Gespräche mit Stefan George (Düsseldorf: H. Kupper, 1963), 42.

${ }^{36}$ Wrighton, Ethics and Politics in Modern American Poetry, 2.

${ }^{37}$ Lisa Saltzman and Eric Rosenberg, eds, Trauma and Visuality in Modernity (Hanover: University Press of New England, 2006), ix-x.

38 Jones, Irrational Modernism: A Neurasthenic History of New York Dada, 28. Jones rereads New York Dada by developing a model of 'irrational modernism' that is both figurative in the art rebellion of the Baroness, and intended as a disruptive counter-force to the rationalizing processes of art history and institutional critique.

${ }^{39}$ Dickerman, 'Introduction', 2.

40 See Gammel, Baroness Elsa: Gender, Dada, and Everyday Modernity - A Cultural Biography, 382.

${ }^{41}$ Friedrich Nietzsche, 'On Self-Overcoming', in The Portable Nietzsche, ed. and trans. Walter Kaufmann (New York: Penguin Books, 1976), 228. 
${ }^{42}$ Walter Kalaidjian argues that the temporal structure of trauma is one of a 'future anterior' whereby we live 'within the deferred action of its unfolding event.' See American Poetry and the Traumatic Past: The Edge of Modernism (Baltimore: John Hopkins University Press, 2006), 5.

${ }^{43}$ Gammel, Baroness Elsa: Gender, Dada, and Everyday Modernity - A Cultural Biography, 12.

${ }^{44}$ Adam McKible, 'Life is Real and Life is Earnest: Mike Gold, Claude McKay, and the Baroness Elsa von Freytag-Loringhoven', American Periodicals: A Journal of History, Criticism, and Bibliography, 15:1 (2005), 58.

${ }^{45}$ Christopher Breu, 'Disinterring the Real: Dodie Bellamy's The Letters of Mina Harker and the Late-capitalist Literature of Materiality', Textual Practice, 26:2 (2012), 285.

${ }^{46}$ Pinthus, Menschheitsdämmerung: Symphonie jüngster Dichtung, xii.

${ }^{47}$ See Peter Middleton, Distant Reading: Performance, Readership, and Consumption in Contemporary Poetry (Tuscaloosa: University of Alabama Press, 2005), 9, 23.

${ }^{48}$ Derek Attridge, The Singularity of Literature (London: Routledge, 2004), 71.

${ }^{49}$ Jacques Lacan, The Seminar of Jacques Lacan: Book II The Ego in Freud's Theory and in the Technique of Psychoanalysis, 1954-55, trans. Sylvana Tomaselli (Cambridge: Cambridge University Press, 1988), 164.

${ }^{50}$ Derek Attridge, The Singularity of Literature, 64.

${ }^{51}$ Margaret Anderson, My Thirty Years' War: An Autobiography (New York: Covici, Friede, 1930), 178.

${ }^{52}$ Alex Goody, Modernist Articulations: A Cultural Study of Djuna Barnes, Mina Loy and Gertrude Stein (New York: Palgrave MacMillan, 2007), 116.

${ }^{53}$ Alex Houen, 'Introduction: Affecting Words', Textual Practice, 25:2 (2011), 218, 219.

${ }^{54}$ Simon Jarvis, 'To the Letter', Textual Practice, 25:2 (2011), 242. 
${ }^{55}$ Breu, 'Disinterring the Real: Dodie Bellamy's The Letters of Mina Harker and the Latecapitalist Literature of Materiality', 285.

56 Ibid, 269.

${ }^{57}$ Melba Cuddy-Keane, 'Narration, Navigation, and Non-conscious Thought: Neuroscientific and Literary Approaches to the Thinking Body', University of Toronto Quarterly, 79 (2010), 680.

${ }^{58}$ By foregrounding the construction of a re-presented body the Baroness also achieves what Kimberly Lamm observes in her poetry: 'densely physical performances [...] that block the assumption that the body from which they emerge is accessible, unprotected by the paternal signifier, and therefore up for grabs.' See Lamm, 'Readymade Baroness: The Gendered Language of Dadaist Dress' (2011), Jacket 2, accessed November 13, 2012, http://www.jacket2.org/article/readymade-baroness.

59 Cuddy-Keane, 'Narration, Navigation, and Non-conscious Thought: Neuroscientific and Literary Approaches to the Thinking Body', 680.

${ }^{60}$ Elsa von Freytag-Loringhoven, 'Letter to Peggy Guggenheim, 29th August 1927'. Series 2, Box 1, Folder 18 (Elsa von Freytag-Loringhoven papers, Special Collections, University of Maryland Libraries).

${ }^{61}$ Freytag-Loringhoven, 'Letter to Sarah Freedman'.

${ }^{62}$ Ibid.

${ }^{63}$ In the absence of the ethical, as the philosopher Emmanuel Levinas explains, 'Love remains a relation with the Other that turns into need'. Such absence becomes apparent in the Baroness's poem as the reader/lover must speculate in which direction it is to have gone 'away from me?' See Totality and Infinity, trans. A. Lingis (1961; Pittsburgh: Duquesne University Press, 1994), 255. 
${ }^{64}$ Bruce Andrews, Paradise and Method: Poetics and Praxis (Evanston: Northwestern University Press), 46, 29.

${ }^{65}$ Dickerman, 'Introduction', 7.

${ }^{66}$ Walter Benjamin, 'Das Kunstwerk im Zeitwalter seiner technischen Reproduzierbarkeit' (The Work of Art in the Age of Mechanical Reproduction), in Illuminations, trans. Harry Zohn (New York: Schocken Books, 1968), 238.

${ }^{67}$ Dickerman, 'Introduction', 7.

${ }^{68}$ Robert Eaglestone, 'One and the Same? Ethics, Aesthetics, and Truth', Poetics Today, 25:4 (2004), 598.

${ }^{69}$ Kinzel, 'Configuration and Government', 750.

${ }^{70}$ Emmanuel Levinas, Otherwise Than Being: or Beyond Essence, trans. A. Lingis (1974;

Pittsburgh: Duquesne University Press, 1999), 73.

${ }^{71}$ Calum Neill, Lacanian Ethics and the Assumption of Subjectivity (Basingstoke: Palgrave MacMillan, 2011), 16.

${ }^{72}$ Freytag-Loringhoven, 'Letter to Peggy Guggenheim, 29 ${ }^{\text {th }}$ August 1927'.

${ }^{73}$ Tzara, 'Introduction to Dada', 394. 